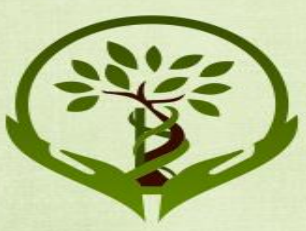

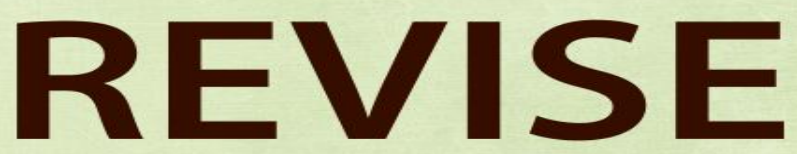

Revista integrativa em inovação tecnológica nas ciências da saúde

\title{
Conferência: O CUIDAR DO TERREIRO
}
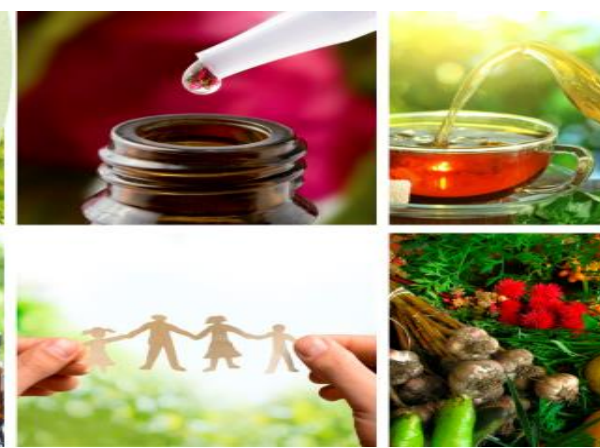

Vanda Machado

Renafro

\section{RESUMO}

O artigo registra as conferências do congresso internacional de inovação tecnológica nas ciências da saúde: a sustentabilidade das práticas integrativas a agroecologia, mais especificamente a conferência $O$ cuidar do terreiro. A conferência enfatiza que as folhas, as rezas e a imposição das mãos conservam práticas ancestrais da medicina negra: a expressão musical "Três folhas de Oxum, três folhas de Ogum", significa que algumas rezas são três galhos, outras são cinco galhos, algumas tem posição em relação ao sol ou na casa. O evento aconteceu de 15 a 18 de novembro de 2017 no IFBA SAJ sob a direção da Universidade Federal do Recôncavo da Bahia.

Palavras-chave: Fitoterapia. Espiritualidade. Folhas. Rezas. Imposição das mãos.

\section{ABSTRACT}

The article registers the conferences of the international congress on technological innovation in health sciences: the sustainability of integrative practices in agroecology, specifically the conference Caring for the yard. The conference emphasizes that the leaves, prayers and the laying on of hands preserve ancient practices of black medicine: the musical expression "Three leaves of Oxum, three leaves of Ogum" means that some prayers are three branches, others are five branches, some has position in relation to the sun or in the house. The event took place from November 15 to 18, 2017 at IFBA SAJ under the direction of the Federal University of Recôncavo da Bahia.

Keywords: Phytotherapy. Spirituality. Sheets. Pray Laying on of hands. 

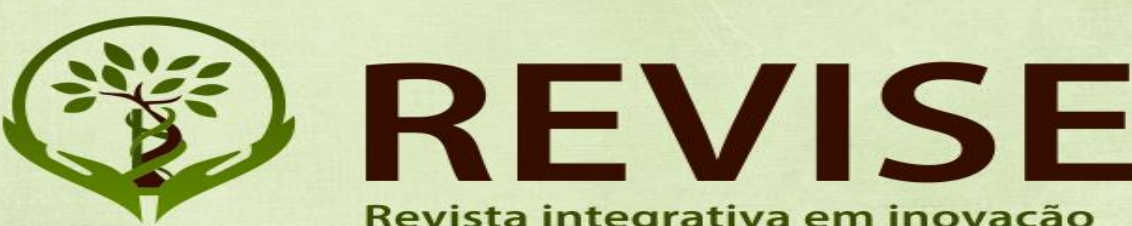

Revista integrativa em inovação tecnológica nas ciências da saúde

ISSN: 2179-6572

\section{Conferência}

Falar de religião de afrodescendentes é considerá-la uma família. Apesar dos maus tratos sofridos no período escravocrata conseguimos ser pessoas bonitas, afetivas, amorosas. O primeiro sinal de cura de doenças nos terreiros é o acolhimento. Esse acolhimento começou nos quilombos: Somos ensinados nas religiões de matrizes africanas a não devolver os maus tratos dos não-negros. Os primeiros negros fugidos pensaram ser possível viver como irmãos. Nos quilombos acolhemos os convidados quando chega. Nós nos abraçamos muito. Nós nos olhamos muito. Quando fui para o terreiro de candomblé eu não fui para ser iniciada. Estava apaixonada pelo marido, fazendo mestrado e desejava fazer um projeto para crianças negras na Bahia/Brasil. Salvador tem $88 \%$ de negros.

Quem precisa saber da história dos negros não precisa ser apenas os negros, mas os brancos também. A medicina foi criada na África, por exemplo, a primeira cirurgia cardíaca foi feita por um jardineiro, narrada no filme "Quase deuses" (2004), do diretor Joseph Sargent. Os professores negros são os primeiros a não saber da própria origem. Nunca houve uma mercadoria mais cara, que valesse mais, do que um ser humano negro; chegaram no Brasil os melhores, mais fortes e mais inteligentes. Por quantas coisas os negros escravos passaram. Os maus tratos, contatos nas narrativas entre gerações não impediram os negros atuais a continuar a serem fortes. No documentário do projeto para crianças negras, a exibição dos minutos iniciais do documentário "O Cuidar no Terreiro"

https://www.youtube.com/watch?v=VyR5jVYohA8 lembrou que a relação de filhos e mães e irmãos ocorre com todos que vivem no terreiro.

O vídeo aponta a importância das crianças conhecerem a mitologia negra. Sentir o cheiro é se aproximar, saber descrever o olho do outro, perceber o outro na sua estrutura física. O olhar, a prática, não é mágica, mas cuidado. Enquanto professora, muitas vezes observei que as coisas não dão certo porque não interessam aos envolvidos com o ensino e aprendizado. Alguns professores não relaciona o conteúdo com a vida de cada um. O ensino e cuidado do terreiro passa por dar e receber, mesmo para quem não acredita em orixás. "Três folhas de Oxum, três folhas de Ogum", como aprender isso? Deve-se considerar que na relação ensino-aprendizagem o outro sabe algo. Eu aprendo porque preciso e aprendo porque quero fazer com outro. No Candomblé a pessoa não é um aluno, sem luz, mas alguém que está aprendendo. Com as rezas se vai aprendendo. Algumas rezas são três galhos, outras são cinco galhos, algumas tem posição em relação ao sol ou na casa etc. "Rezar tem ciência", deve-se saber quando arriar as folhas que estamos rezando. Após um padre proibir as rezas, um surto de sarampo fez com que as rezas voltassem. Ao rezar alguém, deve ter também alguém te rezar. No Candomblé a cura é o cuidado. Em uma casa de lençóis brancos com cheiro de folhas e incensos se faz a cura. A medicina biomédica é usada e os remédios chegaram as práticas medicinais dos religiosos, mas as folhas e as rezas conservam práticas ancestrais. 